\title{
Do financial technology firms influence bank performance? A reverse engineered pitch
}

\author{
Nurhastuty K. Wardhani ${ }^{\mathrm{a}, 1}$ \\ ${ }^{a}$ University of Queensland, Australia and Trisakti University, Indonesia
}

\begin{abstract}
This brief essay uses the pitching research initiated by Faff $(2015,2019)$ to find a new research direction in financial technology (Fintech). The pitch structure underscores the key components of research strategically. The objective of this study is to explore a new area by adopting the reverse-engineering method. The author believes that this method provides the fastest way to learn and research the new topic without leaving the root of the old one.
\end{abstract}

Keywords: Pitching research, Reverse Engineer; Financial Technology; Bank

JEL codes: M1; G23; G21

\section{Introduction}

"The Only Thing That Is Constant Is Change." (Heraclitus)

We live in an undreamt-of era. Technology touches on all aspects of our lives, bringing with it speed and efficiency. Innovative financial has lead financial institutions to offer new services. Borrowing money, making a payment for a bill, and investing in the small-capitalization market can be done in seconds through our telephones. It can be frightening for the old players like the banking industry, but it can be enlightening for millennials and generation $\mathrm{Z}$.

\section{The reverse engineering process}

Financial technology is defined as the adoption of technology to yield novel and reinvigorated financial services (Thakor, 2020). Financial technology (fintech)

\footnotetext{
1 Corresponding author: Nurhastuty K. Wardhani, UQ Business School, University of Queensland, Australia, email address: n.wardhani@business.uq.edu.au
} 
brings to the consumer the promise of better financial services by minimizing e cost and accelerating the approval of a particular loan or transaction. An examination of financial technology, is justified by several considerations. First, financial technology is a relatively new trend, which is less than 10 years old, and is an interplay between innovation in information technology and financial services. This trend became stronger in 2020 as Covid-19 paralysed the world due to lock down and fear of the virus. Second, financial technology is still interconnected with the banking industry, which is the subject of my dissertation. In the last year of my $\mathrm{PhD}$ candidature, I am trying to be more creative, but without leaving the root of my research. Finally, I chose this topic as the study is feasible and affordable to early career researchers like me. I provide a sample of pitch execution in Table 1 based on a paper published in the Pacific Basin Finance journal about the impact of Fintech on bank performance.

\section{A. Working title}

The title of this working paper is "Do Financial Technology Firms Influence Bank Performance? A Reverse Engineered Pitch." The title is based on the main paper with more emphasis on a reverse-engineered process. I believe that this working title is succinct and reflects the interlinkage between financial technology and the banking industry by providing the main of research question.

\section{B. Basic research question}

The main research question is whether financial technology affects bank performance. This question derives from the extent to which banks will be affected by financial technology and to what degree financial technology firms will be substitutes for banks. I argue that the research question is not a subtle balance between the broad topic and the specific question. In fact, the research question seems to simplify the broad topic of financial technology.

\section{C. Key papers}

I believe that I have chosen the best papers at the intersection of the financial technology and banking industry. First, I chose Thakor's conceptual paper Thakor in the Journal of Financial Intermediation (2020). This conceptual paper argues for the necessity of adjusting financial intermediation theory in the context of financial technology and demonstrates in brief how financial technology comprehensively influences the banking industry starting from platform to P2P platforms, cryptocurrencies, and Blockchain. Second, I chose the empirical paper by Cheng and $\mathrm{Qu}$ (2020) in Pacific-Basin Finance. This empirical paper highlights that financial technology alleviates bank risk in terms of credit risk, which is one step after bank performance. Third, I chose Demir's et al. (2020) empirical paper in the European Journal of Finance as one of the key papers due to its different perspectives on the role of financial technology. These three key papers have been published in leading journals and provide robust empirical evidence in underlining the impact of financial technology on the banking industry. 


\section{D. Motivation/puzzle}

Consumer theory (Aaker \& Keller, 1990) and disruptive innovation theory (Christensen, 1999) motivate this study. The motivation is sound and academically persuasive. The motivation connects to the real world by linking Fintech as a new player and the banking industry as the old player in financial services. As both theories view that new players will challenge the existence of old players, the motivation is well-understood and justifiable.

\section{E. Idea}

The idea of this study is compelling and concise. The main hypothesis is very logical and consistent with the big idea that financial technology affects the banking industry negatively. Nevertheless, the endogeneity issue has not been stated explicitly. Currently, it is difficult to explore the natural experiment setting due to different regulatory treatment between financial technology and banking industry. Overall, the idea is consistent with the working title, basic research question, key papers, and motivation.

\section{$\underline{2 F . \text { Data }}$}

The data covers very small observations of a sample, which is fewer than 500 observations, due to the new object of the sample. The sampling decision is realistic as it contains a full sample of financial technology (Fintech) firms and a partial sample of the banking industry with regulatory consideration that differentiates listed and non-listed banks. With respect to banking data, the data can be accessed publicly but the Fintech data needs special access to the Fintech Indonesia Association. The sampling design has perhaps not reached the gold standard for academic research in the field but the efforts should be appreciated.

\section{$\underline{\text { 2G. Tools }}$}

Generally, there is no major issue in relation to the tool. For the purposes of this study, STATA and Python can be applied. The tools are provided and accessible to the researcher. Additionally, the researcher has a standard knowledge of the use of statistical tools and methods. With respect to statistical validity, this study can be applied and reproduced for other countries. Last, the data is compatible with the empirical framework.

\section{H. What's New}

This research offers novelty in terms of ideas and data. The novelty of the idea can be considered as 7 out of 10 as it connects the new players with the older players in financial services and the novelty of the data can be deemed as 8 out of 10 as the Fintech data is not publicly available. With regard to the tools, the novelty can be measured by a standard tool so I value the novelty in terms of Tools as 5 out of 10 . Overall, the idea and the data are the strength of this study. Figure 1 illustrates the best features of the novelty of the pitch through a "Mickey Mouse" diagram. 


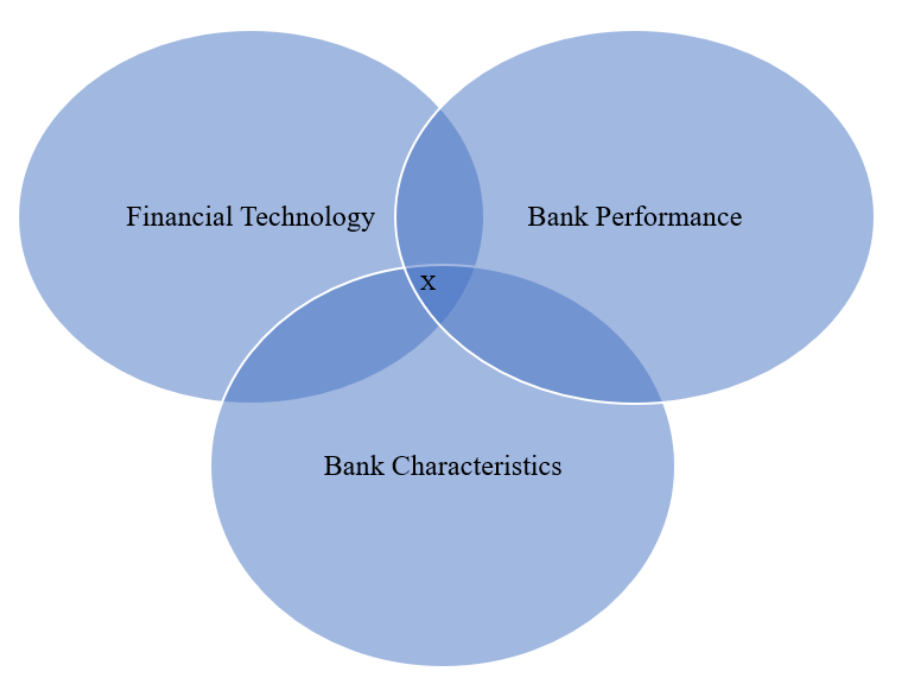

Figure 1. Mickey Mouse diagram reflecting the novelty of the pitch

\section{I. So what}

The empirical findings have strong implications for policymakers and industry players. Since regulators still differentiate the regulation for banking and financial technology, it is important for regulators to evaluate the impact of financial technology on the banking industry. At the same time, the empirical findings are necessary for the banking industry to evaluate the extent to which they have been innovative to compete financial technology. Therefore, I give 8 out of 10 in relation to the policy and industry implications of the empirical findings.

\section{J. Contribution}

The contribution of this study is quite significant and it can be deemed as viable ongoing research. This study can be a stepping-stone for other researchers and can be regarded as one of the pioneers in literature in financial technology in terms of providing empirical evidence. The contribution is aligned with the research question, motivation, idea, data, tools, what's new and so what.

\section{K. Other consideration}

There are several matters that need to be considered in doing research on this topic. First, the risk assessment is realistic. Since this topic is quite new and there is a lack of empirical studies in leading financial journals, the risk of competitors is quite low and the risk of being obsolete is very minimal. The target journal, the Pacific-Basin Finance journal, is fit for purpose. In addition, the scope of the study is a balance between narrow and broad. 


\section{Personal reflection}

I highly recommend the pitching research proposed by Faff $(2015,2019)$ for doctoral researchers and early career researchers to advance their careers. As a doctoral researcher in the final year, it is important to expand my studies into new areas. I have been using this template since I applied for the Ph.D. program at the University of Queensland and the research colloquium at UQ Business School. In particular, I started my Ph.D. in July 2017 and I took RBUS 6914 in my first semester. In that course, I had been introduced by the course coordinator, Professor Robert Faff, to pitching research letter especially reverse engineering. Since then, I find the pitching template beneficial as it accelerates new research for the leading journals.

Regarding financial technology, in the last year I have been asked by a number of people to talk about financial technology for certain communities overseas, such as the Netherlands. At that time, I was not ready and not really familiar with this new topic. Nevertheless, this year has emphasised the importance of financial technology as Covid-19 hit many countries. At the same time, my research journey led me to adopt this new topic. Pitching research by Faff $(2015,2019)$ allowed me to quickly learn this new topic and connected with my original topic. I have never found a quicker learning process than using Faff's template.

\section{Conclusion}

To conclude, the author has adopted the research (Faff, 2015; Faff, 2019) on the reverse engineering pitch for a relatively new trend in finance, which is financial technology. I have disclosed my personal experience with the template and provided a contribution in relation to the pitching research such as Ratiu (2016) and Unda (2015). The author has revealed 11 items that would enhance the doctoral researchers' progress in probing new areas of research.

\section{Acknowledgements}

I would like to thank the anonymous referee for valuable recommendations.

\section{References}

Cheng, M., \& Qu, Y. (2020) "Does bank FinTech reduce credit risk? Evidence from China", Pacific-Basin Finance Journal, vol. 63, no. 1: 101398.

Demir, A., Pesqué-Cela, V., Altunbas, Y., \& Murinde, V. (2020) "Fintech, financial inclusion and income inequality: a quantile regression approach", The European Journal of Finance, no.1: 1-22. 
Faff, R. W. (2015) “A simple template for pitching research", Accounting \& Finance, vol. 55, no. 2: 311-336.

Faff, R. W. (2019) "Pitching research®", Available at SSRN: https://papers.ssrn. com/sol3/Papers.cfm?abstract_id= 2462059 (on-line access: September $1^{\text {st }}$, 2020)

Gabor, D., \& Brooks, S. (2017) "The digital revolution in financial inclusion: international development in the fintech era", New Political Economy, vol. 22, no. 4: 423-436.

Nguyen, B., Faff, R. W., \& Haq, M. (2017) "Pitching research lite: A reverseengineering strategy for finding a new research direction", Available at SSRN: https://papers.ssrn.com/sol3/papers.cfm?abstract_id=2909549 (online access: September $\left.1^{\text {st }} 2020\right)$

Phan, D. H. B., Narayan, P. K., Rahman, R. E., \& Hutabarat, A. R. (2020) "Do financial technology firms influence bank performance?", Pacific-Basin Finance Journal, vol. 62: 101210.

Philippon, T. (2019) "On fintech and financial inclusion", Available at National Bureau of Economic Research: https://nber.org/papers/w26330 (on-line access: September $\left.1^{\text {st }} 2020\right)$

Ratiu, B. A. (2016) A reversed engineered pitch based on Rietveld (2016), "Creating value through the freemium business model: a consumer perspective", Accounting and Management Information Systems, vol. 15, no. 4: 810-818.

Thakor, A. V. (2020) "Fintech and banking: What do we know?", Journal of Financial Intermediation, vol. 41: 100833.

Unda, L. A. (2015) "Board of directors characteristics and credit union financial performance: a Pitch", Accounting \& Finance, vol. 55, no. 2: 353-360 
Table 1. An example of the completed 2-page pitch template of a key paper

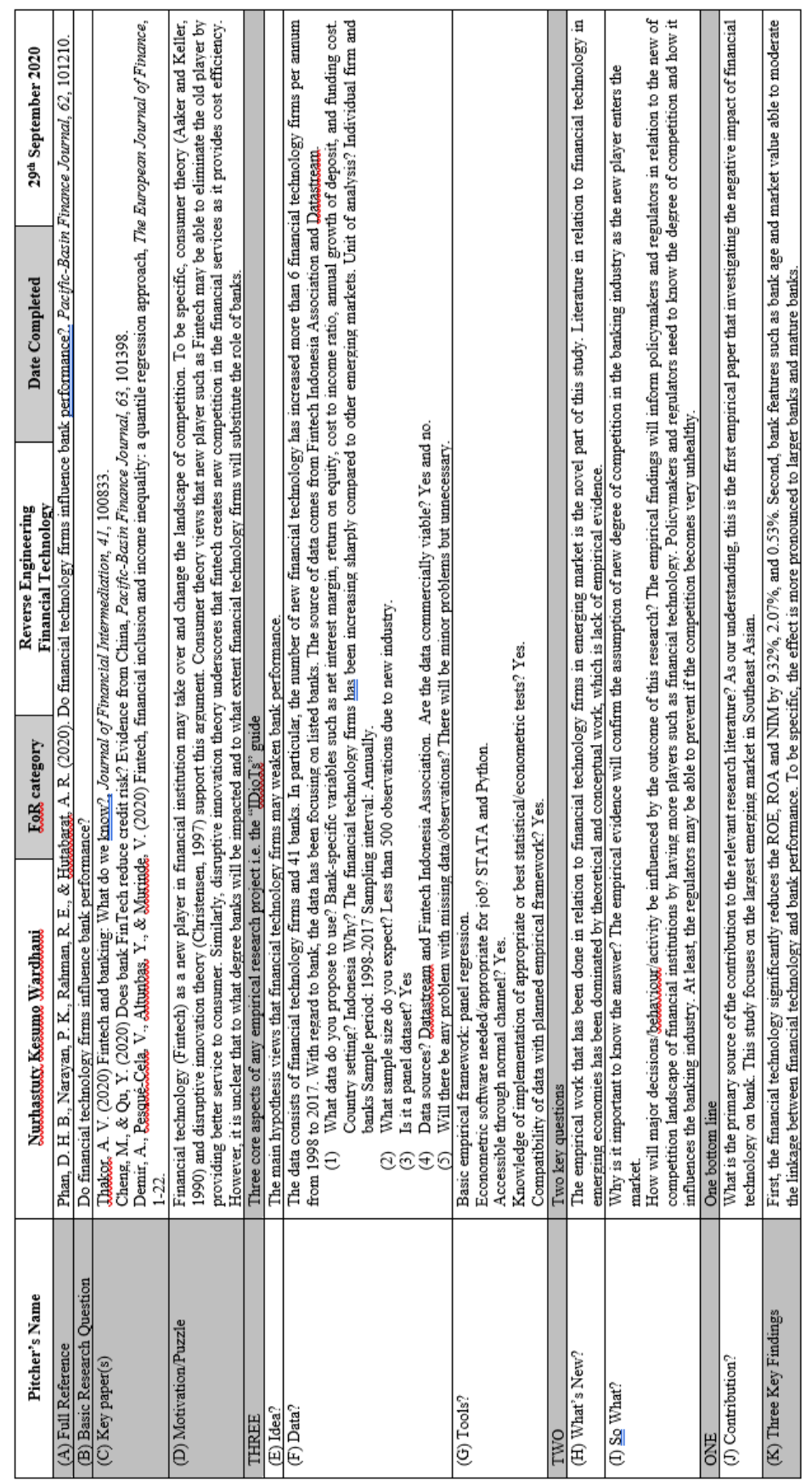

